\title{
The Semio-Pragmatics of Disruption in the Eye Of Youngsters
}

\author{
$1^{\text {st }}$ Jumanto \\ English Department, \\ Faculty of Humanities \\ Universitas Dian Nuswantoro \\ Semarang, Indonesia \\ ilhamj@dsn.dinus.ac.id \\ $4^{\text {th }}$ Rahmanti Asmarani \\ English Department, \\ Faculty of Humanities \\ Universitas Dian Nuswantoro \\ Semarang, Indonesia
}

\author{
$2^{\text {nd }}$ Sarif Syamsu Rizal \\ English Department, \\ Faculty of Humanities \\ Universitas Dian Nuswantoro \\ Semarang, Indonesia
}

\author{
$3^{\text {rd }}$ Haryati Sulistyorini \\ English Department, \\ Faculty of Humanities \\ Universitas Dian Nuswantoro \\ Semarang, Indonesia
}

\begin{abstract}
This research paper has explored the semiopragmatics of disruption in the eye of youngsters, on how the form, the meaning, and the effect are seen by youngsters. The forms and the meanings are obtained from the URLs or web-sites (web-data) and the effects are obtained from the responses by 100 Indonesian millennial youngsters. This research has a semio-pragmatic design with a literature review through interpretive techniques and a coding analysis. The research findings show that disruption commonly refers to the ideologies of disturbance, disorder, interruption, confusion, and break. Most Indonesian youngsters are aware of living in the disruptive era, but they have different responses on the ideologies as well as on disruption as an icon, as an index, and as a symbol. Youngsters also have different opinions on disruptive era as a barrier, as an opportunity, and as a challenge. These positive attitudes of youngsters are beneficial to the advancement of Indonesia, as its young millennial generation are optimistic and prepared to face their future. The government should see this fact and should make efforts to encourage youngsters to exercise as well as to develop their potentials for the present and future advancement of Indonesia.
\end{abstract}

Keywords-Semio-Pragmatics, disruption, eye, youngsters

\section{INTRODUCTION}

Disruption or disruptive in business may refer to creative disruption and disruptive innovation. The former is used to eliminate the existing and a new foundation is to be built to develop the economy [1], while the latter refers to a theory of industry disruption by new technology or products [2]. In this research paper, the word disruption refers to both terminologies in business, which, the authors assume, are still confusing to Indonesian people, especially its youngsters. From this point on, this thesis started to be elaborated.

Is the world today disruptive? This question has probably spread out through various enquiries, ideologies, and even anxieties lived by the world citizens as well as the virtual world netizens. Worlds of business, academia, as well as other institutions may have suffered from the attack of disruptive era along with its automation industry. Like a ghost, the word disruption has been haunting citizens of countries, as well as their businesses and profit-making activities which are so far mostly traditional, descended from family to family, or else, conventional, following the commonly mainstream endeavors. This ghost has come to our dreams, as we have probably, without our knowledge to anticipate, supported the disruptive era to happen, i.e. (1) we have stopped innovating; (2) we count on regulations too much; (3) we do not use technology advancement; (4) we feel satisfied easily; and (5) we do not create a customeroriented relationship [3]. This disruption also happens, as there have been new strategic ways of doing business, from owning (ownership) into sharing (collaboration) [4].

This paradigmatic and phenomenal situation of disruption and disruptive era has also happened in Indonesia. As the word suggests, disruption has created victims, e.g. domestically between conventional taxis and online ones, and globally what previously-noted brands like Nokia, Kodak, and Blackberry have suffered [3]. The former example has led to quarrels, fights, and lawsuits from the conventional drivers or service providers, while the latter has been, based on international news, accepted as failure or unanticipated regrets by the concerned companies.

Disruption and disruptive era has disrupted presumably-settled companies as well as enterprises around the world, and new business players, or the so-called startup businesses have taken the lead in profiting activities towards abundance, a noted newly-termed success in the virtual world, the world of which did not exist and was not very much expected to exist decades ago.

Most peoples or nations in the world are so stunned due to this phenomenal paradigm, and probably do not enjoy seeing this very much, as their mind has been occupied by confusing worries, unexceptionally younger generation, i.e. those who are called millennial generation whose birth-year was among the 1990's and early 2000's. They have 
probably wondered about this disruptive circumstances, and probably have asserted some attitudes, formed opinions, and been affected by ideologies, or thoughts, or particular feelings the world may have missed observing. Are the millennial younger generation, or youngsters, aware of this phenomenal paradigm? What ideologies are most prevailingly supporting these circumstances? Is disruptive era a millennial pride of theirs? How are the effects like, experienced by the youngters throughout their lives as well as within their eye for their future? Is disruptive era an icon, index, or symbol for them within their present time and towards their future? Is it a barrier, opportunity, or challenge for youngsters? This paper has been trying to provide answers to the millennial questions, through a small research conducted to millennial youngsters within a semio-pragmatic research design on disruption and disruptive era.

\section{ABOUT THIS RESEARCH}

This explorative literature and field research employs semiology as well as semiotics, which is then pragmatically elaborated in a survey. A literature research involves different activities, steps of thinking, knowledge advancement as foundation, theory-development facilitation, and open new areas of research [5] [6], embracing synthesis and summary from other works for new ideas, and yielding findings for new theories, both of which are a base for future research [7]. Interpretive techniques are employed in this literature research, as they are the main way of thinking in the research. Some premises are built before the interpreting process is implemented. As believed to be true, a premise can be induced or justified by an argument claim to come to a conclusion [8]. The function of the proposed premises is to limit areas of data verification, knowledge advancement, and theory development on the form, meaning, and effects of disruption elaborated in this research.

The research data obtained from the observation as well as from the questionnaire-based survey through the interpretive techniques are then analysed with a coding technique, i.e. an analysis technique with three steps: open coding, axial coding, and selective coding [9] [10] [11] [12]. The open coding presents and identifies the data into particularly separate concepts. The axial coding reunites the result of the open coding into categories. The selective coding then highlights selected phenomena as the main findings of the research.

The forms and meanings of disruptive are first seen from the Saussurian semiological viewpoints, i.e. to find out the various forms concerned and the ideologies hidden, and the functions of the forms and meanings of disruption are then researched from the Peircian semiotic viewpoints to find out and to verify their effects in the eye of Indonesian youngsters. Youngsters involved in this research refer to the younger generation in their twenties, or those with their birthyear in the 1990's or early 2000's, or we call them the millennial youngsters. The younger generation or the millennial youngsters as subjects of this research are regarded as crucial, as they are part of the citizens as well as the netizens who have lived and learned and probably gotten most affected by this disruptive era.

This semiology/semiotics study is also of pragmatics. Derived from the word "pragmeme" (human act [13]), pragmatics concerns the human acts, which includes verbal acts (or speech acts [14] [15]), and non-verbal acts, i.e. gestures, images, pictures, etc. The term disruption is a verbal act or a speech act or an utterance, which, in pragmatics, should simultaneously have a locution (form), an illocution (meaning), and a perlocution (effect). The forms and meanings of disruption are elaborated from the Saussurian semiology, which regards that a sign is a dyadic entity, of form (signifier) and meaning or ideology (signified) [16] [17]. Meanwhile, the effects of disruption are researched from the Peircian semiotics, which regards that a sign is a triadic entity, of icon, index, and symbol [18] [19]. The purpose of this research is to see the icon, the index, and the symbol of disruption from the eye of Indonesian youngsters. An icon refers to identity, an index to causality, and a symbol to arbitrary nature of the sign disruption. Meanwhile, the eye in this context may refer to close observation, point of view, and judgment [20]. The forms and meanings of disruption are obtained from URLs or websites in the internet (or termed here: web-data), while the effects of disruption are interpreted from the eye of Indonesian youngsters, i.e. to see their close observation, point of view, and argument, through a survey with questionnaires to 100 (one hundred) Indonesian youngsters.

From the research methodology above, the semiopragmatics of disruption is accounted for within two research premises below.

- That disruption refers to various forms and meanings concerning different ideologies; and

- That the effects of disruptive era are differently experienced by youngsters.

These two premises should induce the findings and discussions in a synthesis, and bring the points into an end in the conclusion.

\section{FINDINGS AND DISCUSSIONS}

\section{A. The Various Forms and Meanings of Disruption}

The Premise 1 (P-1) of the research suggests that disruption refers to various forms and meanings concerning different ideologies, thus applying the Saussurian semiological viewpoints, a sign as a dyadic entity of form and meaning. To come to various forms of disruption, an observation on disruption synonyms from 10 URLs or web-sites in the internet (web-data) has been conducted. The 10 web-data have given different accounts on disruption. The web-data 1 [21] suggests that disruption is synonymous to the terms interruption, break, separation, severance, splitting, confusion, disorder, disturbance, and agitation. The webdata 2 [22] suggests the terms derangement, dislocation, disturbance, and upset, while the web-data 3 [23] refers to the terms disturbance, interruption, disorderliness, obstruction, and holding up.

The web-data 4 [24] suggests that disruption is synonymous to the terms disturbance, disorder, interruption, break, confusion, turmoil, disarray, chaos, commotion, and perturbation, while the web-data 5 [25] suggests the terms interposition, interpolation, break, interruption, dislocation, surprisal, perturbation, disturbance, tumultuousness, and upheaval. Meanwhile, the web-data 6 [26] refers to the terms splitting, severance, separation, disorder, disturbance, and agitation.

The web-data 7 [27] suggests that disruption is synonymous to the terms disturbance, interference, 
confusion, upset, disarrangement, disarranging, disarray, disordering, disorderliness, and interruption, while the webdata 8 [28] refers to the terms disturbance, confusion, disarray, and disorder. Meanwhile, the web-data 9 [29] refers to the terms disturbance, interruption, disorder, break, and confusion, and the web-data 10 [30] suggests the terms confusion, disarray, disorder, disorderliness, disturbance, interference, interruption, and stoppage.

Based on the account above, disruption has suggested or referred to various terms or forms. Upon the identification of terms or forms and meanings or ideologies in the open coding and the axial coding, the selective coding has directed us to the biggest five terms or forms of disruption, i.e. (1) disturbance $(10 ; 32.26 \%)$, (2) disorder $(6 ; 19.35 \%)$, (3) interruption $(6 ; 19.35 \%)$,

(4) confusion $(5 ; 16.13 \%)$, and $(5)$ break $(4 ; 12.91 \%)$, as can be seen in Fig. 1.

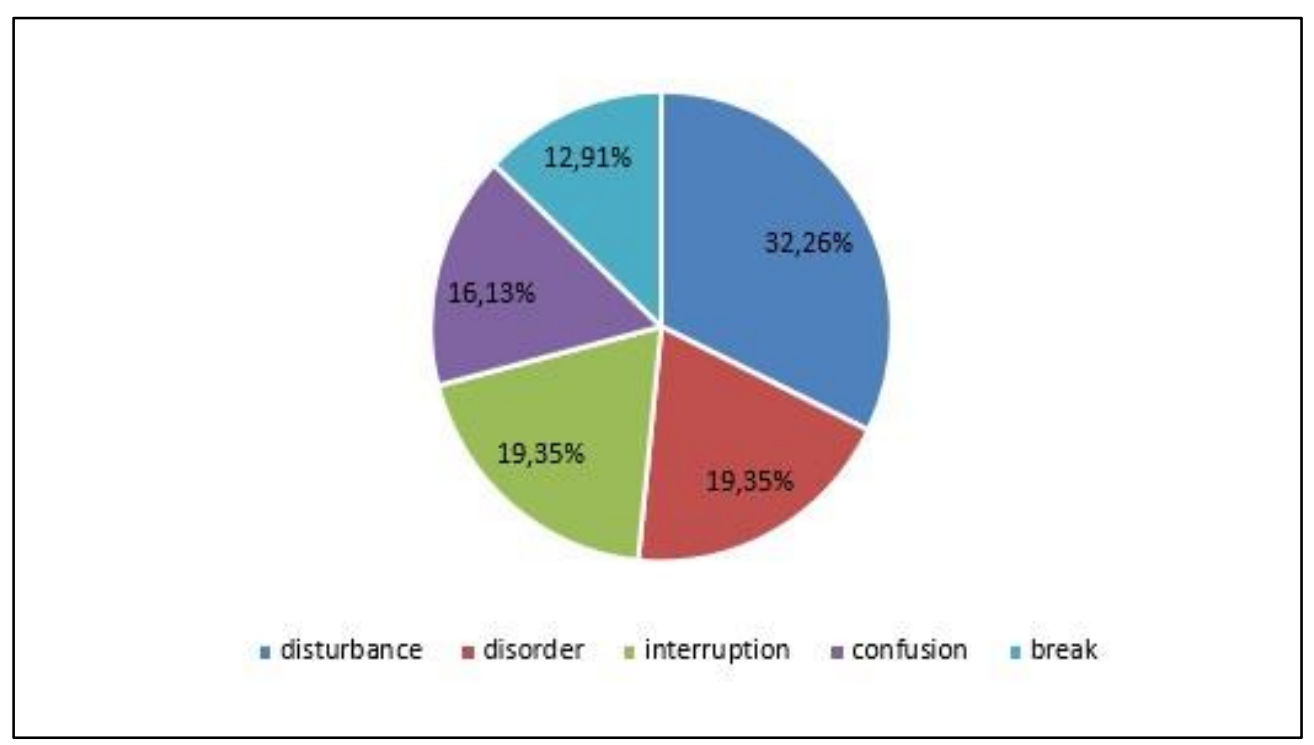

Fig. 1. The five biggest terms or forms of disruption based on the web-data

Based on this result on various terms or forms of disruption, the meanings or ideologies of disruption are then consulted with 3 distinguished online dictionaries, i.e. Cambridge [31], Oxford [32], and Merriam-Webster [20] in the account below.

Disruption as disturbance is defined as something that interrupts someone or makes someone fee worried [31]; the interruption of a settled and peaceful condition [32], or the act of disturbing: the state of being disturbed [20]. From these three definitions, disruption as disturbance means an interruption or the act of disturbing to someone or a settled and peaceful condition. Disruption as disorder is defined as a state of untidiness or lack of organization [31]; a state of confusion [32]; or lack of order [20]. From these three definitions, disruption as disorder means a state of confusion, lack of organization and order. Meanwhile, disruption as interruption is defined as an occasion when someone or something stop something from happening for a short period [31]; the action of interrupting or being interrupted [32]; or a break in the continuity of something [20]. From these three definitions, disruption as interruption means the action of interrupting or stopping something from happening for a short period or breaking its continuity. Disruption as confusion is defined as a situation in which people do not understand what is happening, what they should do or who someone or something is [31]; uncertainty about what is happening, intended, or required [32]; or an act or instance of confusing [20]. From these three definitions, disruption as confusion means a confusing or uncertain situation about what is happening and what to do.
Finally, disruption as break is defined as an interruption [31]; an interruption of continuity or uniformity [32]; or an act or action of breaking [20]. From these three definitions, disruption as break means an interruption, or action of breaking the continuity or uniformity of something.

From the identification of various meanings of disruption, the five basic meanings of disruptio can be inferred as follows:

- As disturbance, disruption is the act of disturbing or an interruption to someone or a settled and peaceful condition.

- As disorder, disruption is a state of confusion, lack of organization and order.

- As interruption, disruption is the action of interrupting or stopping something from happening for a short period or breaking its continuity.

- As confusion, disruption is a confusing or uncertain situation about what is happening and what to do.

- As break, disruption is an interruption, or action of breaking the continuity or uniformity of something.

The Premise 1 (P-1) of the research suggests that disruption refers to various forms and meanings concerning different ideologies. From the accounts on various forms and meanings above, the web-data have confirmed on the premise. Disruption has been proven to refer to the various terms or forms, i.e. disturbance, disorder, interruption, 
confusion, and break, and the meanings of which are the main ideologies of disruption.

B. The Effects of Disruption in the Eye of Youngsters Based on the 12 research questions for the effects of disruption surveyed to the 100 Indonesian millennial youngters, the overall performance can be seen in Table 1 .
The research questions have been converted into statements which are then summed up into 12 points of responses in Table 1. The overall12 points of questions, with the responses from the youngsters in three categories, i.e. disagreement, neutrality or no idea, and agreement, are shown in Table I.

TABLE I. THE OVERALL OBSERVATIONS ON DISRUPTION AND RESPONSES ON DISRUPTIVE ERA BY MILLENNIAL YOUNGSTERS

\begin{tabular}{|c|l|c|c|c|}
\hline \multirow{2}{*}{ No } & \multicolumn{1}{|c|}{ Points of Questions } & \multicolumn{3}{c|}{ Responses } \\
\cline { 3 - 5 } & & Not agree & $\begin{array}{c}\text { Neutral/ } \\
\text { no } \text { idea }\end{array}$ & Agree \\
\hline 1 & Awareness of 4.0 disruptive era & 2 & 14 & 84 \\
\hline 2 & Disruption as disturbance & 31 & 45 & 24 \\
\hline 3 & Disruption as disorder & 30 & 39 & 31 \\
\hline 4 & Disruption as interruption & 44 & 38 & 18 \\
\hline 5 & Disruption as confusion & 40 & 33 & 27 \\
\hline 6 & Disruption as break & 25 & 34 & 41 \\
\hline 7 & $\begin{array}{l}\text { Disruptive era as icon of } \\
\text { millenial pride }\end{array}$ & 15 & 42 & 43 \\
\hline 8 & $\begin{array}{l}\text { Disruptive era as index of } \\
\text { present and future world } \\
\text { advancement }\end{array}$ & 7 & 10 & 83 \\
\hline 9 & $\begin{array}{l}\text { Disruptive era as symbol of chaos (failure), } \\
\text { confusion (lay-people), and abundance (success) }\end{array}$ & 23 & 32 & 45 \\
& & & & 82 \\
\hline 10 & & & & \\
\hline 11 & Disruptive era as a barrier & 57 & 19 & 76 \\
\hline 12 & Disruptive era as an pportunity & 3 & 15 & 82 \\
\hline
\end{tabular}

The first research question is about awareness of 4.0 disruptive era by the Indonesian millennial youngsters. The finding shows that most youngsters are aware of living in the disruptive era (84\%), while a few youngsters (14\%) are not very sure or neutral whether they are aware or not aware. Almost no youngsters $(2 \%)$ are not aware of living in the era, the configuration of which can be better depicted in Fig. 2.

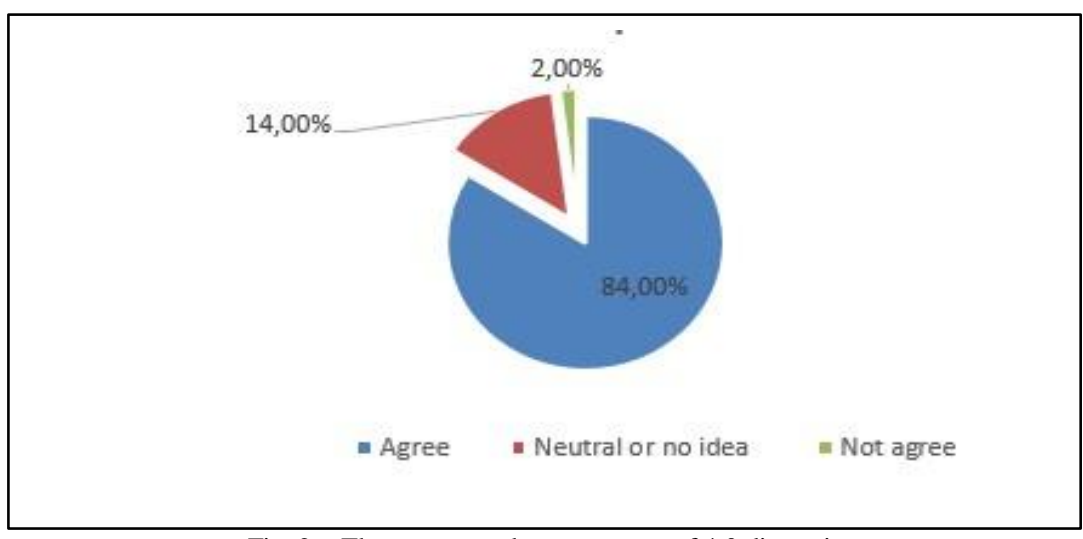

Fig. 2. The awareness by youngsters of 4.0 disruptive era.

Several opinions as well as attitudes concerning the awarenes are that youngsters see that the world is changing and getting more modern, that new technology brands emerge, the old ones are forgotten, that advanced technology effects much in the people's economy, that whatever it takes is done, especially towards the emergence of online shops, that online transports are easier and cheaper, that people are pros and cons about the disruption era, that internet makes everything easier, that conflicts happen between traditional and online trnsports, that they use online shopping themselves, and that they once experienced some horrible service in traditional mode. Meanwhile, youngsters who are not very sure of the awareness have reasons that they are neutral or are not very aware of the condition. There are no comments from the very few youngsters who are not aware of the condition.

The next research questions to be discussed here are about the five common meanings or ideologies behind 
disruption, i.e. disturbance, disorder, interruption, confusion, and break in the eye of youngsters. Based on the research finding in this context, observable in Table 1, we can see that youngsters share their disagreement, neutrality/no idea, and agreement on disruption as disturbance, disorder, interruption, confusion, and break, almost equally, i.e. disagreement $(31 \%, 30 \%, 44 \%, 40 \%$, $25 \%)$, neutrality/no idea $(45 \%, 39 \%, 38 \%, 33 \%, 34 \%)$, and agreement $(24 \%, 31 \%, 18 \%, 27 \%, 41 \%)$. Interestingly noted here is that almost half of youngsters do not agree on disruption as interruption (44\%), and almost half of youngsters $(45 \%)$ have no idea about disruption as disturbance. Meanwhile, almost half of youngsters (41\%) agree on disruption as break, the configuration of which can be observed in Fig. 3.

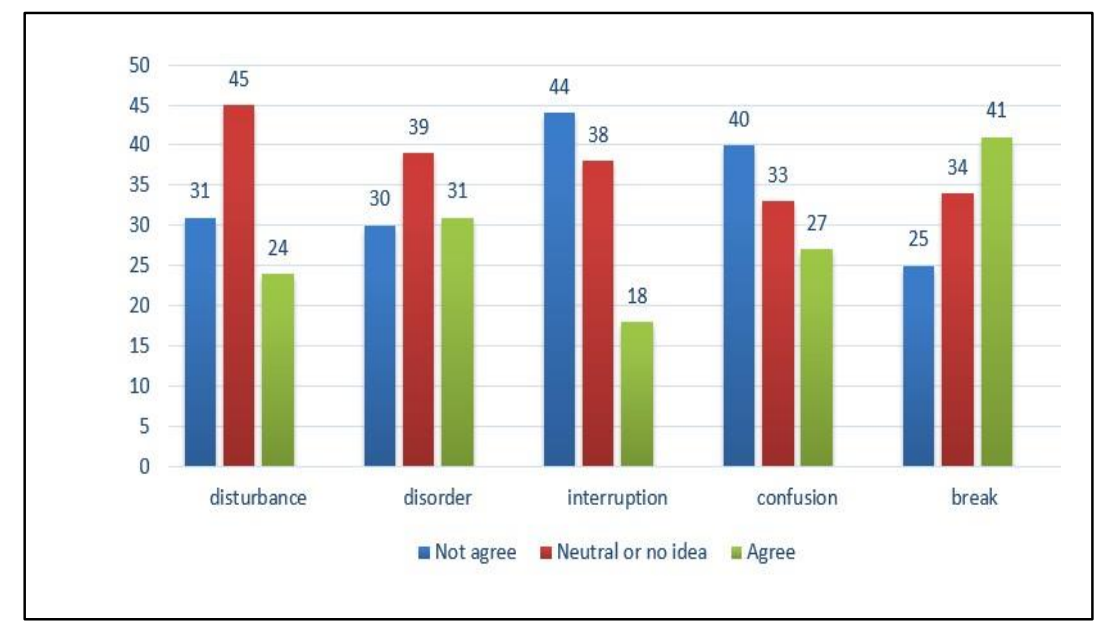

Figure 3. The five meanings or ideologies of disruption in the eye of youngsters.

From Fig. 3, we can learn that more youngsters see disruption as disturbance in a neutral way, but give no comments. Interestingly, fewer youngsters see that disruption is not disturbance with some reasons, i.e. that disruption is important to change the market structure, that settled companies get stronger in the disruptive era, that what happens is not stopping activities, but updating the technologies, and that human beings should compete to advance. Youngsters who see disruption as disturbance also have some reasons, i.e that retail stores are affected badly, that that is how life goes, and that growing companies might lose the competition, as new technologies emerge. From Fig. 3, we can also learn that more youngsters see disruption as disorder in a neutral way, as they are confused and they see that disruption is the effect of technology advancement. Fewer youngsters see that disruption is not disorder with the reasons that what is feared does not happen yet, that only those conservational will not be able to respond positively, and that disruption is of effects from world advancement. Meanwhile, another fewer youngsters who see disruption as disorder also have the reasons that disruption causes unbalanced market, that many people cannot deal with this growth of era, that people today are easy to be affected, so they easily misunderstand and get crazy, that not all people feel the change the same, that some people are still not updated, while some others are not used to it, and that company growth is a subject to change, not of certainty.

Figure 3 shows us that more youngsters do not see disruption as interruption with the reasons that the interruption is not happening totally, that disruption benefits companies and their consuments more, and that disruption is a good reference for industries to compete for innovations. Meanwhile, fewer youngsters see disruption as interruptin in a neutral way with the only reason that the interruption is not happening yet. A very few youngsters see disruption as interruption with the reasons, i.e. that disruption refers to modernization and that disruption advances technology. Figure 3 also shows us that more youngsters do not see disruption as confusion with the reason that research and adaptation to information concerning the situation will help their understanding disruption. Meanwhile, fewer youngsters see disruption as confusion in a neutral way, but give no comments. A few youngsters see disruption as confusion with some reasons, i.e. that the quality is probably different between goods in the real market and in the virtual one, that disruption is happening now, and that growing companies may be threatened in competition by the new ones. Meanwhile, disruption as break shows different performance. More youngsters see disruption as break with no comments, so do fewer youngsters see it as break in a neutral way, with no comments. Another few youngsters do not see disruption as break, with the reasons that they are not able to adjust to the condition that they think that disruption is more of modernization, and that disruption has $50-50$ probability to break.

The next research questions to be discussed here are about the interpretation of disruption in the eye of youngsters. As have been mentioned above, the interpretation on disruption by youngsters are researched from the Peircian semiotic viewpoints, i.e. a sign as a triadic entity, to see disruptive era as an icon (identity), an index (causality), and a symbol (common belief) of the world advancement. Based on the research finding in this context, observable in Table 1 , we can see that almost equally half of youngsters ( $43 \%$ and $42 \%$ ) see disruptive era as an icon of their millennial pride and have no idea, while a few 
youngsters (15\%) do not agree on this pride. Most youngsters $(83 \%)$ see that disruptive era is an index of present and future world advancement, while only $10 \%$ have no idea and $7 \%$ do not agree on this index. Almost half of youngsters $(45 \%)$ see disruptive era as a symbol of chaos, confusion, and abundance, but $32 \%$ have no idea and $23 \%$ do not agree on this symbol. The configuration of disruptive era as a sign in the eye of youngsters can be observed in Fig. 4.

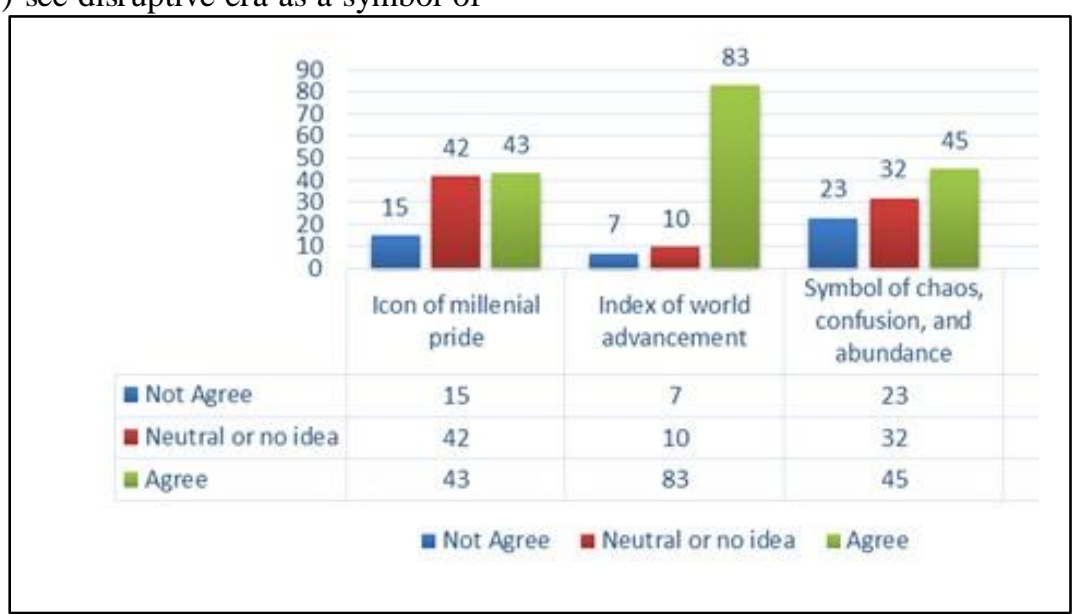

Fig. 4. Disruptive era as a sign in the eye of youngsters.

Almost equal numbers of youngsters see disruptive era as an icon of millennial pride and and see disruptive era in a neutral way. The former number has the reasons that disruptive era supports particular lifestyles, that Indonesia supports the most recent technology advancement, and that disruptive era makes everything more practical. Meanwhile, the latter number has the reasons that disruptive era is not that good, that it is more difficult in a particular service, that besides a pride, disruptive era is also something good, and that not everybody is very fond of it. A few youngsters do not see disruptive era as an icon of millennial pride, as they think that disruptive era elliminates job opportunities in the real world.

Most youngsters see disruptive era as an index of world advancement with the reasons that Indonesia is on the way to modernity and to being an advanced country, that technology is everywhere today, that grocery prices should not rise in line with advancing technology, that disruption is interesting, but has nothing to do with the emergence of a new era, and that disruptive era is indeed a sign of advancement. A very few youngsters have a neutral opinion, as they are sure that disruptive era has positive and negative aspects. The other very few youngsters do not see disruptive era as an index of world advancement and give no comments.
More youngsters see disruptive era as a symbol of chaos, confusion, and abundance. Their reasons among others are that the era is of high competition, that those who learn fast or update themselves get smarter, and those who do not get left behind, and that we should adjust ourselves to the disruptive era for success, not for failure. Fewer youngsters have a neutral opinion on disruptive era as a symbol of chaos, confusion, and abundance, as they think that it depends on what people think and see. The other fewer youngsters do not see disruptive era as that symbol, as they think that consumers' want is unpredictable and their demands are subject to change.

The next research questions are about how youngsters form their opinions as the effects of disruptive era, whether they see the era as a barrier, an opportunity, and a challenge. Based on Table 1, the finding shows that more than half of youngsters (57\%) do not see disruptive era as a barrier, $35 \%$ have no idea, and only $8 \%$ see disruptive era as a barrier. Most youngsters (76\%) see disruptive era as an opportunity, $19 \%$ have no idea, and only $5 \%$ do not agree on this opportunity. Most youngsters (82\%) see disruptive era as a challenge, $15 \%$ have no idea, and only $3 \%$ do not agree on this challenge. The configuration of opinions of youngsters on this barrier, opportunity, and challenge can be observed in Figure 5. 


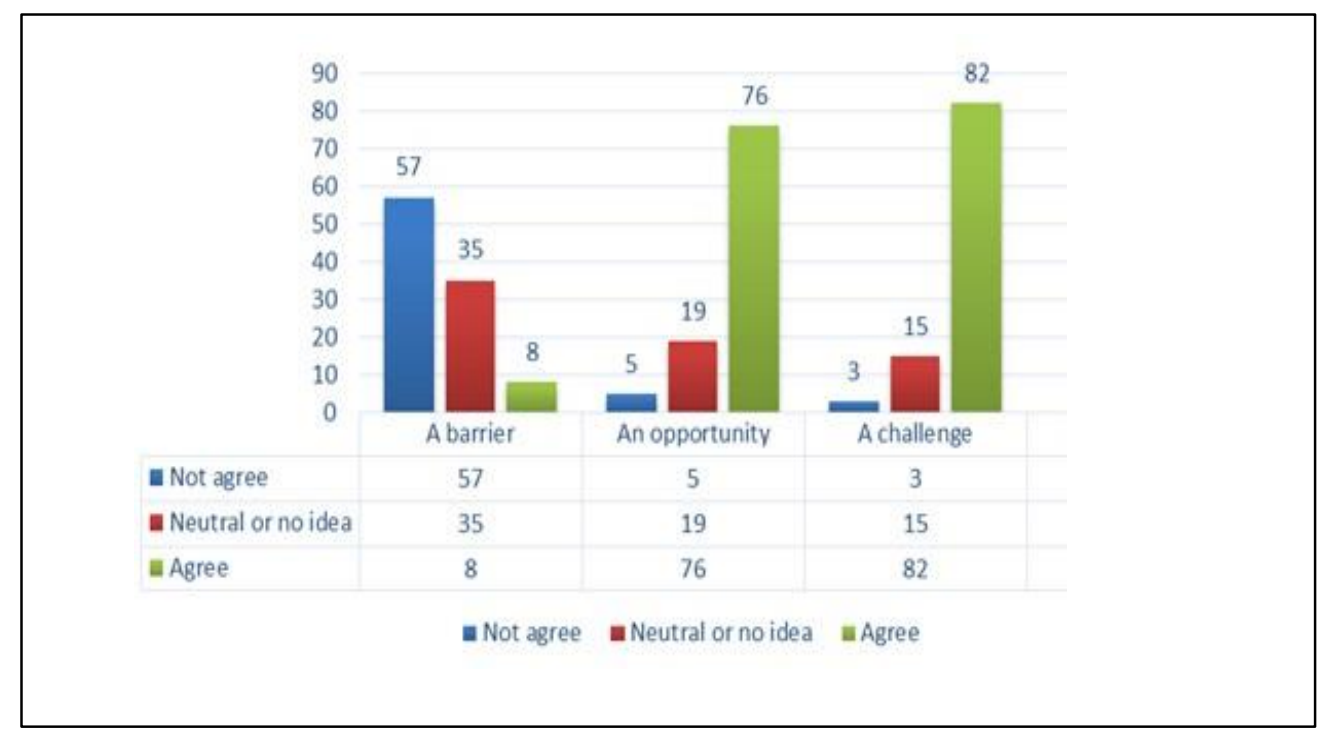

Fig. 5. Disruptive era effect in the eye of youngsters

More youngsters do not see disruptive era as a barrier, as they need to enhance their broadview of thinking, their career is not very affected or disturbed by the barrier thought, and they think that this era is merely one phase among the others in life. Fewer youngsters have a neutral opinion, as they think they are just following the wind of life. The very few others see disruptive era as a barrier, as they think that this is the era of automation.'

Most youngsters see disruptive era as an opportunity, as they think that the era eases one's career to advance, that the era provides an open opportunity to being YouTubers, and that they realize that they are students of younger generation. A very few youngsters with a neutral opinion give no comments. Meanwhile, the very few others do not see disruptive era as an opportunity, as they think that success depends on one's efforts. The last but not least, most youngsters see disruptive era as a challenge with reasons that the era is a challenge to change their mindset, that aspects of advancement encourage them to perform more and better to update themselves, that this era may result in disorder, so they love new challenges for their future, that disruptive era is full of challenges, and that new challenges are new careers ahead. A very few youngsters have a neutral opinion on disruptive era as a challenge and give no comments. Meanwhile, the very few others do not see disruptive era as a challenge and give no comments.

\section{CONCLUSION AND RECOMMENDATION}

Disruption commonly refers to disturbance, disorder, interruption, confusion, and break, and the meanings of which are the main ideologies of disruption. Most Indonesian youngsters are aware of living in the disruptive era, have different responses on the ideologies, and almost equally share their opinions. However, almost half of youngsters do not agree on disruption as interruption, and almost a half of them have no idea about disruption as disturbance. Almost a half of youngsters agree on disruption as break. Indonesian youngsters should learn more about disruption and thorough lessons should be taught to them for better comprehension and elaboration for their future.

Almost equally a half of youngsters see disruptive era as an icon of their millennial pride, but the other half have no idea about the pride. Most youngsters see disruptive era as an index of present and future world advancement. However, almost a half of youngsters see disruptive era as a symbol of chaos, confusion, and abundance. This is interesting, as youngsters should be self-confident to face their future, despite the myths contained in disruptive era as a symbol. The myths should, however, be accounted for and clarified by understanding experts in semiology as well as semiotics, concerning the signification on youngsters' negative feelings (chaos and confusion), besides their positive feelings (towards abundance and success).

More than a half of youngsters do not see disruptive era as a barrier, but most youngsters see disruptive era as an opportunity and a challenge. These three positive attitudes of youngsters are beneficial to the advancement of Indonesia, as its young millennial generation are optimistic and prepared to face their future. The government should see this fact and should make efforts to encourage youngsters to exercise as well as to develop their potentials for the present and future advancement of Indonesia.

\section{ACKNOWLEDGMENT}

The authors would like to acknowledge as well as to extend their high gratitude to the 100 Indonesian enthusiastic millennial youngsters, who have been willing to be the subjects of this research and who have contributed their great participation in this non-profit research project. The gratitude also goes to the President or the Rector of Universitas Dian Nuswantoro (UDINUS), Indonesia, Professor Edi Noersasongko, who has encouraged the completion of this research project.

\section{REFERENCES}

[1] J. Cornwall, The Entrepreneurial Mind, May 2013.

[2] J.L. Bower and C.M. Christensen, "Disruptive technologies: catching the wave", Harvard Business Review, JanuaryFebruary, 1995.

[3] S. Liani, "Mengenal era disrupsi (disruption era) dan strateg menghadapinya", 24 September 2018, available at https://blog.ruangguru.com/perhatikan-hal-hal-ini-untukbertahan-di- era-disrupsi-disruption-era

[4] R. Kasali, Disruption: Tak Ada yang Tak Bisa Diubah Sebelum Dihadapi, Motivasi Saja Tidak Cukup, Jakarta: Gramedia Pustaka Utama, 19 February 2017. 
[5] M.J. Baker, "Writing a literature review", The Marketing Review, 1(2), 219-247, 2000, available at https://doi.org/10.1362/1469347002529189.

[6] J. Webster and R.T. Watson, "Analyzing the past to prepare for the future: writing a literature review", MIS Quarterly, 26(2), xiiixxiii, 2002.

[7] Bolderston, "Writing an effective literature review", Journal of Medical Imaging and Radiation Sciences, 39, 86-92, 2008, available at https://doi.org/10.1016/j.jmir.2008.04.009.

[8] R. Audi, ed., The Cambridge Dictionary of Philosophy (2nd ed.). Cambridge: Cambridge University Press, 1999.

[9] J. Strauss and J. Corbin, Basics of Qualitative Research: Grounded Theory Procedures and Techniques, California: Sage Publications, 1990.

[10] Holloway, Basic Concepts for Qualitative Research, Oxford: Blackwell Science Ltd., 1997.

[11] Bohm, "Theoretical coding: text analysis in grounded theory", A Companion to Qualitative Research, U. Flick, E. Kardorff \& I. Steinke (eds.), London: Sage Publications, 2004, pp. 270-275.

[12] J. Saladana, "The coding manual for qualitative researchers", London: Sage, ISBN 1446247376, 2012.

[13] J.L. Mey, Pragmatics: An Introduction (2nd ed), Oxford: Blackwell Publishing, 2001.

[14] J.L. Austin, How to Do Things with Words, Oxford: Clarendon, 1962.

[15] J.R. Searle, Speech Acts: An Essay in the Philosophy of Language, Cambridge: Cambridge University Press, 1969.

[16] R.Barthes, Elements of Semiology (Translated by Annette Lavers \& Colin Smith), London: Jonathan Cape, 1967.

[17] R. Barthes, Mythologies, New York: Hill \& Wang, 1987.

[18] U. Eco, A Theory of Semiotics, London: Macmillan, 1976.

[19] U. Eco, Semiotics and the Philosophy of Language, Bloomington: Indiana University Press, 1986.

[20] Merriam-Webster, Merriam-Webster, since 1928, available at https://www.merriam-webster.com/

[21] Web-data 1, "disruption", Thesaurus, retrieved May 2019.

[22] Web-data 2, "disruption", Merriam-Webster, retrieved May 2019.

[23] Web-data 3, "disruption", en-oxforddictionaries, retrieved May 2019.

[24] Web-data 4, "disruption", powerthesaurus, retrieved May 2019.

[25] Web-data 5, “disruption”, synonym, retrieved May 2019.

[26] Web-data 6, "disruption", thesaurus-yourdictionary, retrieved May 2019.

[27] Web-data 7, "disruption”, wordhippo, retrieved May 2019.

[28] Web-data 8, "disruption”,collinsdictionary, retrieved May 2019.

[29] Web-data 9, "disruption", synonym-tech, retrieved May 2019.

[30] Web-data 10, "disruption", dictionary-reverso-net, retrieved May 2019.

[31] Cambridge, Cambridge Dictionary, available at https://dictionary.cambridge.org/dictionary/english/

[32] Oxford, English, Oxford Living Dictionary, available at https://en.oxforddictionaries.com/ 